\title{
Sources and Deposition of Reactive Gaseous Mercury in the Marine Atmosphere
}

\section{Citation}

Holmes, Christopher D., Daniel J. Jacob, Robert P. Mason, Daniel A. Jaffe. 2009. Sources and deposition of reactive gaseous mercury in the marine atmosphere. Atmospheric Environment 43(14): 2278-2285.

\section{Published Version}

doi:10.1016/j.atmosenv.2009.01.051

\section{Permanent link}

http://nrs.harvard.edu/urn-3:HUL.InstRepos:3553957

\section{Terms of Use}

This article was downloaded from Harvard University's DASH repository, and is made available under the terms and conditions applicable to Other Posted Material, as set forth at http:// nrs.harvard.edu/urn-3:HUL.InstRepos:dash.current.terms-of-use\#LAA

\section{Share Your Story}

The Harvard community has made this article openly available.

Please share how this access benefits you. Submit a story.

Accessibility 


\title{
Sources and deposition of reactive gaseous mercury in the marine atmosphere
}

\author{
Christopher D. Holmes ${ }^{a}, *$, Daniel J. Jacob ${ }^{a}$, Robert P. Mason ${ }^{b}$, Dan A. Jaffe ${ }^{c}$ \\ ${ }^{a}$ Department of Earth and Planetary Sciences, School of Engineering and Applied Sciences, Harvard University, Cambridge, MA 02138, USA \\ ${ }^{\mathrm{b}}$ Department of Marine Science, University of Connecticut, Groton, CT 06340, USA \\ ${ }^{\mathrm{c}}$ Interdisciplinary Arts and Sciences, University of Washington-Bothell, Bothell, WA 98011, USA
}

\section{A R T I C L E I N F O}

\section{Article history:}

Received 1 October 2008

Received in revised form

23 January 2009

Accepted 25 January 2009

\section{Keywords:}

Mercury deposition

Marine boundary layer

Atmospheric mercury chemistry

Tropospheric halogen chemistry

\begin{abstract}
A B S T R A C T
Observations of reactive gaseous mercury (RGM) in marine air show a consistent diurnal cycle with minimum at night, rapid increase at sunrise, maximum at midday, and rapid decline in afternoon. We use a box model for the marine boundary layer (MBL) to interpret these observations in terms of RGM sources and sinks. The morning rise and midday maximum are consistent with oxidation of elemental mercury $\left(\mathrm{Hg}^{0}\right)$ by $\mathrm{Br}$ atoms, requiring $<2$ ppt $\mathrm{BrO}$ in most conditions. Oxidation of $\mathrm{Hg}^{0}$ by $\mathrm{Br}$ accounts for $35-60 \%$ of the RGM source in our model MBL, with most of the remainder contributed by oxidation of $\mathrm{Hg}^{0}$ by ozone (5-20\%) and entrainment of RGM-rich air from the free troposphere (25-40\%). Oxidation of $\mathrm{Hg}^{0}$ by $\mathrm{Cl}$ is minor (3-7\%), and oxidation by $\mathrm{OH}$ cannot reproduce the observed RGM diurnal cycle, suggesting that it is unimportant. Fitting the RGM observations could be achieved in the model without oxidation of $\mathrm{Hg}^{0}$ by ozone (leaving $\mathrm{Br}$ as the only significant oxidant) by increasing the entrainment flux from the free troposphere. The large relative diurnal amplitude of RGM concentrations implies rapid loss with a lifetime of only a few hours. We show that this can be quantitatively explained by rapid, masstransfer-limited uptake of RGM into sea-salt aerosols as $\mathrm{HgCl}_{3}^{-}$and $\mathrm{HgCl}_{4}^{2-}$. Our results suggest that $80-$ $95 \%$ of $\mathrm{Hg}^{\mathrm{II}}$ in the MBL should be present in sea-salt aerosol rather than gas-phase, and that deposition of sea-salt aerosols is the major pathway delivering $\mathrm{Hg}^{\mathrm{II}}$ to the ocean.
\end{abstract}

(c) 2009 Elsevier Ltd. All rights reserved.

\section{Introduction}

Atmospheric deposition is the principal source of mercury to the ocean (Lindberg et al., 2007). Human industry has increased this source by about a factor of three relative to natural conditions (Mason and Sheu, 2002), resulting in a corresponding increase in the surface ocean pool and raising concerns about mercury accumulation in marine biota (Mergler et al., 2007). Mercury is emitted to the atmosphere mainly as elemental mercury $\left(\mathrm{Hg}^{0}\right)$ and is oxidized within the atmosphere to $\mathrm{Hg}^{\mathrm{II}}$, which is highly watersoluble and the major depositing form (Lindberg et al., 2007). A critical step towards understanding the deposition of mercury to the ocean is quantifying the supply of $\mathrm{Hg}^{\text {II }}$ to the atmospheric marine boundary layer (MBL), which extends about $1 \mathrm{~km}$ above the ocean surface and is in turbulent contact with it. We apply here a box model for the MBL to analyze several recent data sets of reactive gaseous mercury (RGM, representing gaseous $\mathrm{Hg}^{\mathrm{II}}$ ) over the North Atlantic and Pacific Oceans (Laurier et al., 2003; Jaffe

\footnotetext{
* Corresponding author at: Department of Earth and Planetary Sciences, School of Engineering and Applied Sciences, Harvard University, Pierce Hall Room 110I, 29 Oxford St., Cambridge, MA 02138, USA. Tel.: +1 617384 7813; fax: +1 6174954551. E-mail address: cholmes@seas.harvard.edu (C.D. Holmes).
}

et al., 2005; Laurier and Mason, 2007), in order to better understand the $\mathrm{Hg}^{\text {II }}$ budget in the MBL and the implications for ocean uptake.

Mercury has an atmospheric lifetime of 0.5-1 years, enabling transport on a global scale (Lindberg et al., 2007). Oxidation of $\mathrm{Hg}^{0}$ must be photochemical, as evidenced by the observed seasonal cycle of $\mathrm{Hg}^{0}$ (Selin et al., 2007) and by the diurnal cycle of RGM (Laurier and Mason, 2007). But it is still unclear which oxidants dominate. Standard models assume gas-phase $\mathrm{OH}$ and ozone to be the main oxidants (Shia et al., 1999; Petersen et al., 2001; Cohen et al., 2004; Lin et al., 2006; Seigneur et al., 2006; Selin et al., 2007; Sillman et al., 2007). However, recent thermodynamic and kinetic analyses suggest that these reactions are extremely slow in the atmosphere (Calvert and Lindberg, 2005; Hynes et al., 2008). Gasphase oxidation by $\mathrm{Br}$ atoms is known to cause rapid loss of $\mathrm{Hg}^{0}$ in the Arctic boundary layer in spring, an environment with particularly active bromine chemistry (Goodsite et al., 2004; Brooks et al., 2006; Tackett et al., 2007). Holmes et al. (2006) suggested that $\mathrm{Br}$ atoms in the free troposphere (above the boundary layer) could provide the main global sink of $\mathrm{Hg}^{0}$.

Mercury-bromine chemistry could also be active within the MBL at low and middle latitudes. Mason and Sheu (2002) proposed that $40 \%$ of $\mathrm{Hg}^{0}$ emitted from the ocean is oxidized within the MBL and deposited back; they implicated halogen oxidants but did not 
offer a specific mechanism. A direct test of $\mathrm{Hg}$-halogen chemistry at a midlatitude coastal site by simultaneous $\mathrm{BrO}$ and RGM measurements was inconclusive due to the high BrO detection limit (2 pptv) (Keene et al., 2007; Laurier and Mason, 2007), but Br could still be important as a $\mathrm{Hg}^{0}$ oxidant at lower BrO concentrations, as demonstrated below. Hedgecock et al. (2003, 2004, 2005, 2006) showed that a box model for the MBL with atomic Br released from sea-salt aerosols could reproduce the mean concentrations and diurnal amplitudes of RGM observed over the Mediterranean Sea. However, the $\mathrm{Hg}+\mathrm{Br}$ reaction kinetics that they used (Ariya et al., 2002) seem too fast in light of recent data (Goodsite et al., 2004; Balabanov et al., 2005; Donohoue et al., 2006; Ariya et al., 2008). As a result, their model required a diurnal cycle in marine $\mathrm{Hg}^{0}$ emission to balance oxidation and thus account for the observed lack of diurnal variation in atmospheric $\mathrm{Hg}^{0}$ concentrations (Hedgecock and Pirrone, 2004). A diurnal cycle of $\mathrm{Hg}^{0}$ emission is difficult to justify, even with photoreduction of $\mathrm{Hg}^{\mathrm{II}}$ in surface water, because the gaseous ventilation time of the marine photic zone is $\sim 1$ month (Strode et al., 2007). We will show that these shortcomings can be corrected while preserving Hedgecock's central result that $\mathrm{Br}$ is a major $\mathrm{Hg}^{0}$ oxidant in the MBL.

\section{Observed RGM diurnal variability}

We analyze reactive gaseous mercury (RGM) data from cruises in the remote Atlantic (Laurier and Mason, 2007) and Pacific Oceans (Laurier et al., 2003), and from coastal measurements in Okinawa, Japan (Jaffe et al., 2005). RGM is the measured gas-phase component of $\mathrm{Hg}^{\mathrm{II}}$, collected here using a $\mathrm{KCl}$ denuder (Landis et al., 2002). The Pacific data were collected between Osaka, Japan and Honolulu, Hawaii over 20 days during May-June 2002. We separated the midlatitude and subtropical data at $27^{\circ} \mathrm{N}$ based on a sharp rise in water and air temperatures. The Atlantic data were collected in subtropical waters between Bermuda and Barbados over 11 days during August-September 2003. In both data sets the RGM concentrations are 2-h averages and the detection limit for individual measurements is $3 \mathrm{pg} \mathrm{m}^{-3}$. We removed data contaminated by the ship's exhaust, which occurred on only one day during the Pacific cruise. The ships also measured $\mathrm{Hg}^{0}, \mathrm{O}_{3}$, and $\mathrm{CO}$ concentrations in addition to standard oceanographic and meteorological variables. Laurier et al. (2003) and Laurier and Mason (2007) provide further details on the cruise tracks and sampling methods.

The Okinawa data span 40 days during March-May 2004. They were collected at the northern tip of the island $\left(26.8^{\circ} \mathrm{N}, 128.2^{\circ} \mathrm{E}\right.$, $60 \mathrm{~m}$ a.s.l.) with prevailing onshore flow. The site has minimal impact from anthropogenic sources on the island. Averaging times for the measurements were $5 \mathrm{~min}$ for $\mathrm{Hg}^{0}$ and $3 \mathrm{~h}$ for RGM and particulate mercury (radii $<1.3 \mu \mathrm{m}$ ). The RGM detection limit for individual measurements is $1 \mathrm{pg} \mathrm{m}^{-3}$. $\mathrm{Hg}^{0}$ at Okinawa is strongly correlated with $\mathrm{CO}$, indicating an East Asian industrial origin, but RGM is not (Jaffe et al., 2005; Strode et al., 2008). We discard 5 days of observations with the greatest pollution transport from continental Asia.

The dominant feature of RGM temporal variability is its diurnal cycle, as shown in Fig. 1. The diurnal cycle is statistically significant ( $p \leq 0.05$ from Kruskal-Wallis test of constant mean) at Okinawa and in the subtropical Atlantic and Pacific data, but is much weaker and does not reach statistical significance in the midlatitude Pacific data $(p=0.2)$. RGM increases rapidly at sunrise, peaks at midday, declines through the afternoon, and falls near detection limit at night. Neither deposition nor boundary layer growth can drive this diurnal cycle, since the winds and MBL depth have little diurnal variability (Hignett, 1991). Rather, RGM production due to changing oxidant levels must be responsible. Although the amplitude of the RGM diurnal cycle varies between the data sets in Fig. 1, the consistent shape and phase argue for a common driving mechanism.

The RGM increase at sunrise suggests a photochemical oxidant produced by photolysis of weakly-bound nighttime reservoirs. $\mathrm{Br}$ and $\mathrm{Cl}$ can exhibit this behavior (von Glasow et al., 2002). By contrast, $\mathrm{OH}$ in the MBL increases only slowly after sunrise and peaks at midday (Nowak et al., 2001). Selin et al. (2007) previously noted that $\mathrm{Hg}^{0}$ oxidation by $\mathrm{OH}$ yields an afternoon peak of RGM delayed by several hours relative to the observations at Okinawa. In contrast to RGM, the $\mathrm{Hg}^{0}$ concentrations in all data sets show no significant diurnal cycle, which places an upper bound on the $\mathrm{Hg}^{0}$ oxidation rate. Given $10 \%$ measurement uncertainty for $\mathrm{Hg}^{0}$ (Jaffe et al., 2005), daytime oxidation must be less than $3-5 \% \mathrm{~d}^{-1}$ or 4-8 $\mathrm{pg} \mathrm{m}^{-3} \mathrm{~h}^{-1}$.

The relative diurnal amplitude of RGM, expressed as the difference between maximum and minimum concentrations divided by the 24-h mean, ranges from 1 to 3 depending on the data set. Concentrations decrease by $40-70 \%$ over the $12-18$ Local Solar Time (LST) period, implying a lifetime of a few hours at most. Nighttime RGM observations tend to decrease as wind speed increases (Fig. 2), suggesting a fast deposition sink rather than chemical loss. Hedgecock and Pirrone (2001) and Selin et al. (2007) previously speculated that uptake by sea-salt aerosols might provide such a fast deposition sink, and we provide further mechanistic support for this hypothesis below.

\section{Model description}

We interpret the observed diurnal cycles of RGM with a box model of the MBL applied to the different data sets of Fig. 1. The model calculates the concentration of gaseous $\mathrm{Hg}^{\text {II }}\left(c, \mathrm{~mol} \mathrm{~m}^{-3}\right)$ based on chemical production and loss $\left(P\right.$ and $\left.L, \mathrm{~mol} \mathrm{~m}^{-3} \mathrm{~s}^{-1}\right)$, dry deposition to the ocean surface $\left(F_{\mathrm{d}}, \mathrm{mol} \mathrm{m}^{-2} \mathrm{~s}^{-1}\right)$, entrainment at the top of the $\operatorname{MBL}\left(F_{\mathrm{e}}, \mathrm{mol} \mathrm{m}^{-2} \mathrm{~s}^{-1}\right)$, and uptake by sea-salt aerosols $\left(J, \mathrm{~mol} \mathrm{~m}^{-3} \mathrm{~s}^{-1}\right)$ :

$\frac{\mathrm{d} c}{\mathrm{~d} t}=P-L+\frac{F_{\mathrm{e}}-F_{\mathrm{d}}}{Z}-J$,

where $Z$ is the MBL depth. Downward fluxes are positive. For comparison with observations we assume that all gas-phase $\mathrm{Hg}^{\mathrm{II}}$ species are measured as RGM.

Table 1 summarizes the model parameters, which are taken from measurements when available. Other parameters are typical MBL values, which suffice to compare proposed alternative $\mathrm{Hg}^{\mathrm{II}}$ formation and loss pathways against RGM data. We choose the concentrations of $\mathrm{Br}$ and free-tropospheric RGM to best match the amplitude and mean of the RGM diurnal cycle in each data set, as described below, then evaluate these concentrations against the few available measurements.

Table 2 lists the kinetic data used to calculate $P$ and $L$. Oxidation to $\mathrm{Hg}^{\mathrm{II}}$ by halogen atoms and $\mathrm{OH}$ proceeds in two addition reactions, in competition with thermal dissociation of the intermediate $\mathrm{HgX}(\mathrm{X} \equiv \mathrm{Br}, \mathrm{Cl}, \mathrm{OH})$. We neglect oxidation initiated by $\mathrm{OH}$ in our reference model due to the instability of $\mathrm{HgOH}$ under atmospheric conditions (Goodsite et al., 2004; Calvert and Lindberg, 2005; Hynes et al., 2008), but we include it in a sensitivity test.

The entrainment flux at the top of the boundary layer is the product of an assumed entrainment velocity $v_{\mathrm{e}}=0.5 \mathrm{~cm} \mathrm{~s}^{-1}$ (Faloona et al., 2005) and the concentration difference between the MBL and the free troposphere $\left(c_{\mathrm{FT}}\right)$ :

$F_{\mathrm{e}}=v_{\mathrm{e}}\left(c_{\mathrm{FT}}-c\right)$.

The dry deposition flux is calculated by applying a deposition velocity $\left(v_{\mathrm{d}}\right)$ to the RGM concentration: 

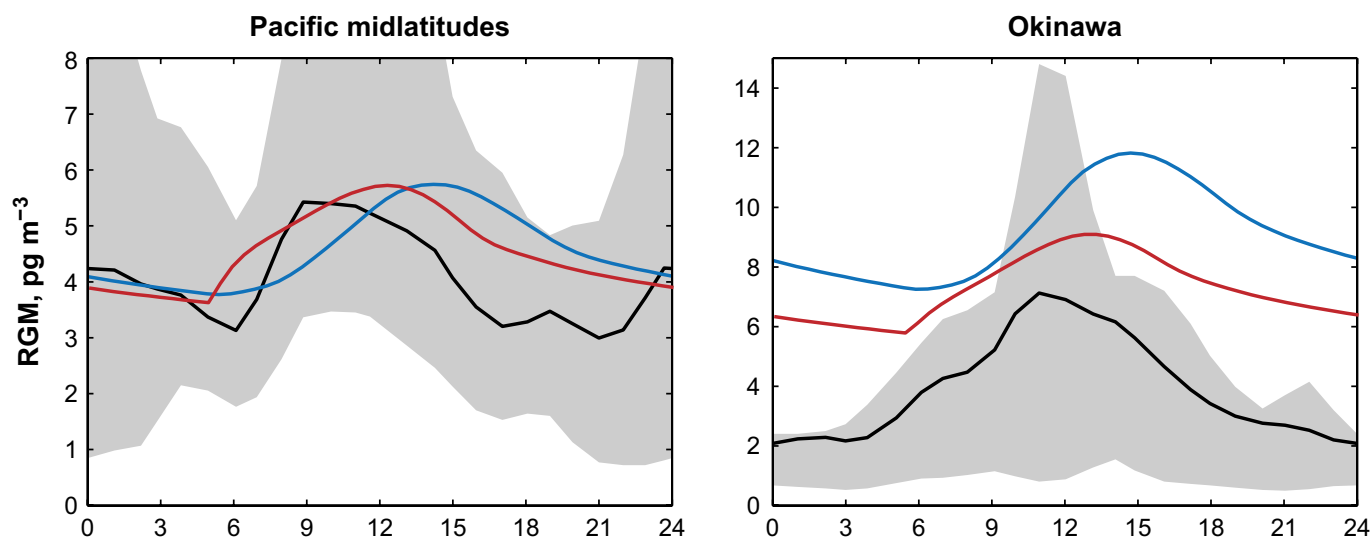

Pacific subtropics

Atlantic subtropics
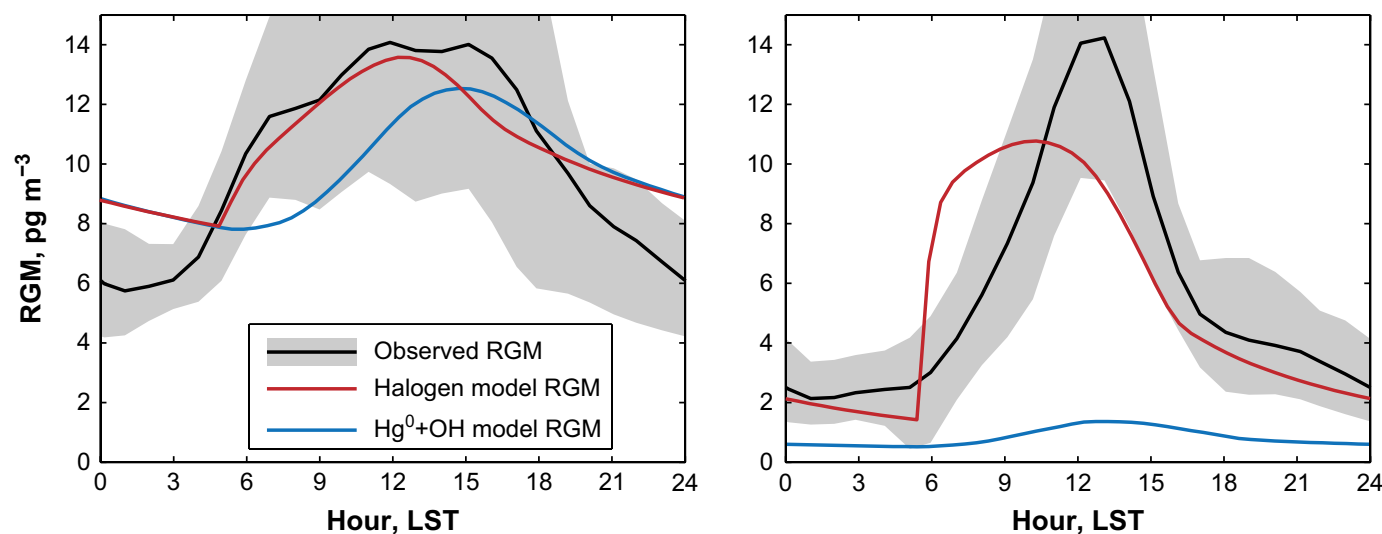

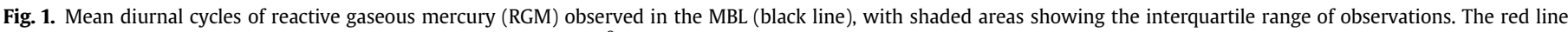

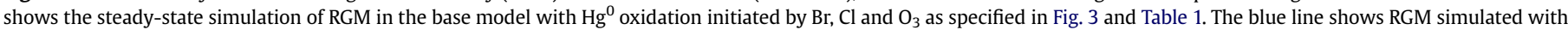

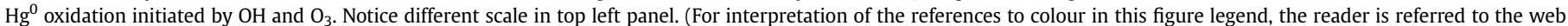
version of this article.)

$F_{\mathrm{d}}=v_{\mathrm{d}} c$.

Due to the high solubility of $\mathrm{Hg}^{\mathrm{II}}$ species in water (Table 2), $v_{\mathrm{d}}$ is limited by aerodynamic resistance. For neutrally stable conditions typical of the marine atmosphere,

$v_{\mathrm{d}}(z)=\frac{k u_{*}}{\ln \left(z / z_{0}\right)}$,

where $k=0.4$ is the von Kármán constant (Seinfeld and Pandis, 2006). Most aerodynamic resistance to deposition occurs in the lowest few meters, so we use a reference height $z=10 \mathrm{~m}$ at which wind speeds were measured. The roughness length $\left(z_{0}\right)$ and friction velocity $\left(u_{*}\right)$ are calculated from the observed wind speed at $10 \mathrm{~m}$ $(u(z))$ by iteratively solving the system of equations (Stull, 1988, pp. 377, 381):

$z_{0}=\alpha_{\mathrm{C}} \frac{u_{*}^{2}}{g}$

$u_{*}=\frac{k u(z)}{\ln \left(\mathrm{z} / z_{0}\right)}$

where $\alpha_{\mathrm{C}}=0.016$ is the Charnock constant and $g=9.8 \mathrm{~m} \mathrm{~s}^{-2}$ is the gravitational acceleration.

We find $v_{\mathrm{d}}=0.4-1.4 \mathrm{~cm} \mathrm{~s}^{-1}$ for the different data sets (Table 1 ). Combined with a typical MBL depth $Z=750 \mathrm{~m}$, these deposition rates imply an RGM lifetime of 15-50 h against dry deposition. This is too slow to explain the rapid decrease observed in the afternoon and evening hours (Fig. 1). A more important pathway for RGM loss may be uptake by sea-salt aerosols followed by aerosol deposition. We assume that all $\mathrm{Hg}^{\text {II }}$ species have the same solubility as $\mathrm{HgCl}_{2}$. Once dissolved in aqueous aerosols or cloud droplets, $\mathrm{Hg}^{\mathrm{II}}$ species convert to $\mathrm{HgCl}_{2}$ due to the abundance of $\mathrm{Cl}^{-}$(Hedgecock and Pirrone, 2001). Complexation of $\mathrm{HgCl}_{2(\mathrm{aq})}$ to $\mathrm{HgCl}_{3}^{-}$and $\mathrm{HgCl}_{4}^{2-}$ preferentially fractionates $\mathrm{HgCl}_{2}$ into the sea-salt aerosol (Table 2) (Hedgecock and Pirrone, 2001). The equilibrium partitioning depends on the sea-salt aerosol chloride concentration, which is a function of the water vapor saturation ratio $(S)$ :

$\left[\mathrm{Cl}^{-}\right]=\frac{\rho_{\mathrm{SS}} f_{\mathrm{Cl}}}{M_{\mathrm{Cl}}}\left(\frac{1-S}{2-S}\right)\left(\frac{3.7}{4}\right)^{3}$,

where $M_{\mathrm{Cl}}=35.5 \mathrm{~g} \mathrm{~mol}^{-1}$ is the atomic weight of $\mathrm{Cl}$, $\rho_{\mathrm{SS}}=2200 \mathrm{~kg} \mathrm{~m}^{-3}$ is the density of dry sea salt, and $f_{\mathrm{Cl}}=0.55$ is the mass fraction of $\mathrm{Cl}$ in dry sea salt. This formula follows from an empirical expression for sea-salt aerosol growth relative to its dry radius $\left(r_{\text {dry }}\right)$ (Lewis and Schwartz, 2006):

$r=r_{\mathrm{dry}} \frac{4}{3.7}\left(\frac{2-S}{1-S}\right)^{1 / 3}$

The relation holds over $0.45<S<0.99$ which spans the range found in the MBL. For typical marine conditions of $S=0.8$ and seasalt aerosol liquid water content $L=1 \times 10^{-10} \mathrm{~m}_{\text {water }}^{3} \mathrm{~m}_{\text {air }}^{-3}$, it follows that $\left[\mathrm{Cl}^{-}\right]=4.5 \mathrm{M}$ and $85 \%$ of total $\mathrm{Hg}^{\mathrm{II}}$ is dissolved in sea-salt aerosol at equilibrium. 


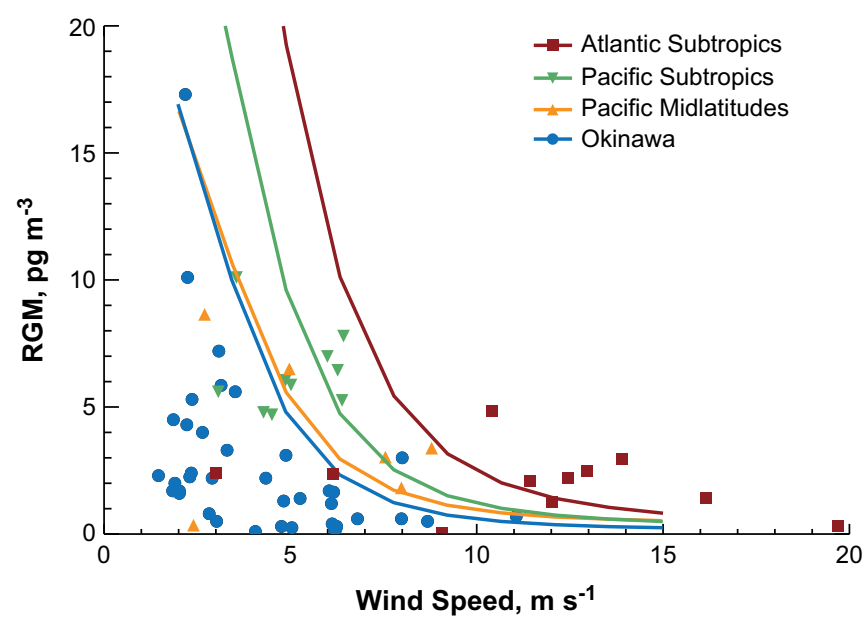

Fig. 2. Nighttime RGM concentrations (0-5 LST) vs. wind speed. Symbols show observed means for individual days. Lines show the relationship predicted by the box model for each data set by varying wind speed while holding other parameters constant.

Because of the short sea-salt aerosol lifetime, one cannot assume RGM to be in equilibrium with the aerosol; RGM uptake is in fact limited by mass transfer. We find that this limitation slows down RGM loss by a factor of $1.5-3$ relative to assuming equilibrium. Let $c_{\mathrm{a}}\left(\mathrm{mol} \mathrm{m}^{-3}\right)$ denote the aqueous-phase concentration of $\mathrm{Hg}_{(\mathrm{aq})}^{\mathrm{II}} \equiv \mathrm{HgCl}_{2(\mathrm{aq})}+\mathrm{HgCl}_{3}^{-}+\mathrm{HgCl}_{4}^{2-}$, and let $H$ be the dimensionless effective Henry's law constant for $\mathrm{HgCl}_{2}$ accounting for the polychloride complexes. The net uptake of $\mathrm{Hg}^{\mathrm{II}}$ by the aerosol is given by

$J=L k_{\mathrm{mt}}\left(c-\frac{c_{\mathrm{a}}}{H}\right)$,

where $k_{\mathrm{mt}}$ is a mass-transfer coefficient to the aerosol. For a monodisperse aerosol with number concentration $N\left(\mathrm{~m}^{-3}\right)$ of particles of radius $r, k_{\mathrm{mt}}$ can be approximated by (Sander, 1999)

$k_{\mathrm{mt}}=\frac{4 \pi r^{2}}{L}\left(\frac{r}{D_{\mathrm{g}}}+\frac{4}{v \alpha}\right)^{-1} N$,

where $D_{\mathrm{g}}=0.1 \mathrm{~cm}^{2} \mathrm{~s}^{-1}$ is the diffusivity of RGM in air, $v=1.5 \times 10^{4} \mathrm{~cm} \mathrm{~s}^{-1}$ is the mean molecular speed, and $\alpha=0.5$ is the assumed accommodation coefficient for $\mathrm{HgCl}_{2}$. Results are insensitive to $\alpha$ in the range $0.1-1$ typical of highly soluble gases.

We calculate RGM uptake by sea-salt aerosol by considering $m=5$ dry aerosol size classes with radius divisions at 1, 3.2, 5.4, 7.6, 9.8 , and $12 \mu \mathrm{m}$. Through sensitivity tests we found that smaller, submicron aerosols are insignificant sinks of RGM because of their small liquid water content while aerosols larger than $12 \mu \mathrm{m}$ are also insignificant sinks because of their small number and short atmospheric residence time. For each size class, we calculate the number concentration by integrating over the steady-state aerosol number distribution governed by the balance between aerosol production (Lewis and Schwartz, 2004, p. 321 lognormal approximation) and loss by dry deposition (Zhang et al., 2001). For simulations over the Mediterranean Hedgecock et al. (2005) assumed fixed $L=3 \times 10^{-11} \mathrm{~m}_{\text {water }}^{3} \mathrm{~m}_{\text {air }}^{-3}$ and an aerosol residence time of 3 days. Using the wind speed from that study $\left(3.8 \mathrm{~m} \mathrm{~s}^{-1}\right)$ and $S=0.8$, we obtain similar values of $L=4.7 \times 10^{-11} \mathrm{~m}_{\text {water }}^{3} \mathrm{~m}_{\text {air }}^{-3}$ and a residence time of 1.8 days averaged over all size classes. The total aerosol uptake in Equation (1) is a sum over the fluxes for each size class: $J=\sum_{i=1}^{m} J_{i}$.

In addition to Equation (1), the model calculates the sea-salt aerosol $\mathrm{Hg}_{(\mathrm{aq})}^{\mathrm{II}}$ concentration:

$\frac{\mathrm{d} c_{\mathrm{a}, i}}{\mathrm{~d} t}=\frac{J_{i}}{L_{i}}-v_{\mathrm{d}, i} \frac{c_{\mathrm{a}, i}}{Z}$.

Here $c_{\mathrm{a}, i}, L_{i}$, and $v_{\mathrm{d}, i}$ are the $\mathrm{Hg}_{(\mathrm{aq})}^{\mathrm{II}}$ concentration, liquid water content, and aerosol deposition velocity for the $i$ th size class. This

Table 1

Box model parameters.

\begin{tabular}{|c|c|c|c|c|}
\hline \multirow[t]{2}{*}{ Parameter } & \multicolumn{4}{|l|}{ Region } \\
\hline & Okinawa & Pacific cruise midlatitudes & Pacific cruise subtropics & Atlantic cruise subtropics \\
\hline \multicolumn{5}{|l|}{ Measured $^{\mathrm{a}}$} \\
\hline$\left[\mathrm{Hg}^{0}\right], \mathrm{ng} \mathrm{m}^{-3}$ & 2.0 & 2.5 & 2.5 & 1.6 \\
\hline$\left[\mathrm{O}_{3}\right], \mathrm{ppb}$ & 31 & 35 & 10 & 13 \\
\hline Temperature, $\mathrm{K}$ & 294 & 283 & 298 & 301 \\
\hline $10-\mathrm{m}$ wind speed, $\mathrm{m} \mathrm{s}^{-1}$ & 4.4 & 5.9 & 5.1 & 11.2 \\
\hline Relative humidity, \% & 80 & 77 & 84 & 75 \\
\hline \multicolumn{5}{|l|}{ Derived $^{\mathrm{b}}$} \\
\hline$v_{\mathrm{d}}, \mathrm{cm} \mathrm{s}^{-1}$ & 0.38 & 0.56 & 0.46 & 1.4 \\
\hline$\left[\mathrm{Cl}^{-}\right], \mathrm{M}$ & 4.5 & 5.1 & 3.8 & 5.4 \\
\hline$H, \mathrm{M} \mathrm{atm}^{-1}$ & $2.6 \times 10^{9}$ & $3.2 \times 10^{9}$ & $1.8 \times 10^{9}$ & $3.7 \times 10^{9}$ \\
\hline$L, \mathrm{~m}_{\text {water }}^{3} \mathrm{~m}_{\mathrm{air}}^{-3}$ & $8.3 \times 10^{-11}$ & $1.6 \times 10^{-10}$ & $1.3 \times 10^{-10}$ & $5.3 \times 10^{-10}$ \\
\hline$F_{\mathrm{V}}, \mathrm{m}_{\text {water }}^{3} \mathrm{~m}_{\text {ocean }}^{-2} \mathrm{~s}^{-1}$ & $3.6 \times 10^{-13}$ & $1.1 \times 10^{-12}$ & $7.1 \times 10^{-13}$ & $8.8 \times 10^{-12}$ \\
\hline $\mathrm{Hg}^{0}$ lifetime, $\mathrm{d}$ & 120 & 140 & 90 & 10 \\
\hline RGM, lifetime, h & 8.1 & 3.8 & 6.7 & 0.7 \\
\hline \multicolumn{5}{|l|}{ Other ${ }^{c}$} \\
\hline$v_{\mathrm{e}}, \mathrm{cm} \mathrm{s}^{-1}$ & 0.5 & 0.5 & 0.5 & 0.5 \\
\hline$Z, \mathrm{~m}$ & 750 & 750 & 750 & 750 \\
\hline$[\mathrm{Br}], \mathrm{cm}^{-3}$ & $4.3 \times 10^{5}$ & $2.0 \times 10^{5}$ & $8.7 \times 10^{5}$ & $4.3 \times 10^{6}$ \\
\hline$[\mathrm{Cl}], \mathrm{cm}^{-3}$ & $1.5 \times 10^{4}$ & $1.5 \times 10^{4}$ & $1.5 \times 10^{4}$ & $1.5 \times 10^{4}$ \\
\hline$[\mathrm{OH}], \mathrm{cm}^{-3}$ & $1.1 \times 10^{6}$ & $6.3 \times 10^{5}$ & $1.2 \times 10^{6}$ & $1.1 \times 10^{6}$ \\
\hline$c_{\mathrm{FT}}, \mathrm{pg} \mathrm{m}^{-3}$ & 10 & 20 & 20 & 20 \\
\hline
\end{tabular}

a Means over the observation period.

b We display $H$ in conventional units here, so one should multiply this by 24 atm $\mathrm{M}^{-1}$ to obtain the dimensionless form used in Equation (9). $F_{\mathrm{V}}$ is the volumetric production

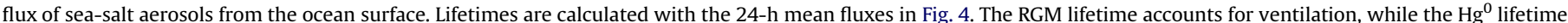
includes only MBL chemical loss. Other derived parameters are calculated from the measurements with the equations in Section 3.

c Other parameters are from literature and models as described in Section 3. [Br], [Cl], and [OH] are 24-h means which multiply the relative amplitudes in Fig. 3. 
Table 2

Chemical reactions and equilibria in the MBL box model.

\begin{tabular}{|c|c|c|}
\hline Reaction or equilibrium ${ }^{a}$ & Rate or equilibrium coefficient ${ }^{\mathrm{b}}$ & Reference \\
\hline$\overline{\mathrm{Hg}^{0}+\mathrm{O}_{3} \rightarrow \mathrm{HgO}+\mathrm{O}_{2}{ }^{\mathrm{c}}}$ & $3.0 \times 10^{-20}$ & Hall (1995) \\
\hline $\mathrm{Hg}^{0}+\mathrm{Br} \stackrel{\mathrm{M}}{\rightarrow} \mathrm{HgBr}$ & $1.1 \times 10^{-12}(T / 298)^{-2.37}$ & Goodsite et al. (2004) \\
\hline $\mathrm{HgBr} \stackrel{\mathrm{M}}{\rightarrow} \mathrm{Hg}^{0}+\mathrm{Br}$ & $1.2 \times 10^{10} \exp (-8357 / T)$ & Goodsite et al. (2004) \\
\hline $\mathrm{HgBr}+\mathrm{Br} \stackrel{\mathrm{M}}{\rightarrow} \mathrm{HgBr}_{2}$ & $2.5 \times 10^{-10}(T / 298)^{-0.57}$ & Goodsite et al. (2004) \\
\hline $\mathrm{HgBr}+\mathrm{OH} \stackrel{\mathrm{M}}{\rightarrow} \mathrm{HgBrOH}$ & $2.5 \times 10^{-10}(T / 298)^{-0.57}$ & Goodsite et al. (2004) \\
\hline $\mathrm{HgBr}+\mathrm{Br} \rightarrow \mathrm{Hg}+\mathrm{Br}_{2}$ & $3.9 \times 10^{-11}$ & Balabanov et al. (2005) \\
\hline $\mathrm{Hg}^{0}+\mathrm{Cl} \stackrel{\mathrm{Y}, \mathrm{M}}{\rightarrow} \mathrm{HgClY}^{\mathrm{d}}$ & $2.2 \times 10^{-32} \exp (680(1 / T-1 / 298))[\mathrm{M}]$ & Donohoue et al. (2005) \\
\hline $\left.\mathrm{HgCl}_{2} \leftrightarrow \mathrm{HgCl}_{2(\mathrm{aq})}\right)^{\mathrm{e}}$ & $1.4 \times 10^{6} \mathrm{M} \mathrm{atm}^{-1}$ & Lindqvist and Rodhe (1985) \\
\hline $\mathrm{HgCl}_{2(\mathrm{aq})}+\mathrm{Cl}^{-} \leftrightarrow \mathrm{HgCl}_{3(\mathrm{aq})}^{-}$ & $6.7 \mathrm{M}^{-1}$ & Clever et al. (1985) \\
\hline $\mathrm{HgCl}_{3(\mathrm{aq})}^{-}+\mathrm{Cl}^{-} \leftrightarrow \mathrm{HgCl}_{4(\mathrm{aq})}^{2-}$ & $13 \mathrm{M}^{-1}$ & Clever et al. (1985) \\
\hline $\mathrm{Hg}^{0}+\mathrm{OH} \rightarrow \mathrm{Hg}^{\mathrm{II}}$ & $0^{\mathrm{f}}$ & \\
\hline
\end{tabular}

a Species are gas-phase except where (aq) indicates aqueous-phase.

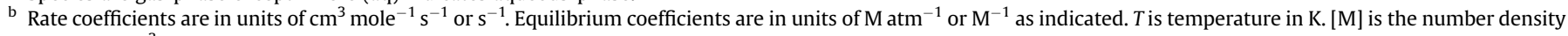
of air in $\mathrm{mol} \mathrm{cm}^{-3}$.

c The mechanism and products of this reaction are poorly understood, and the reaction might be insignificant under atmospheric conditions (Calvert and Lindberg, 2005;

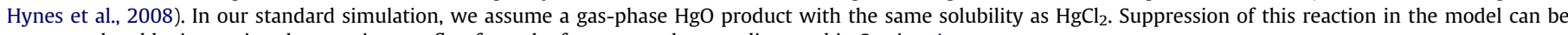
accommodated by increasing the entrainment flux from the free troposphere as discussed in Section 4.

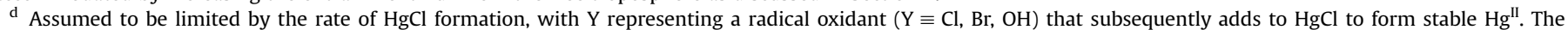

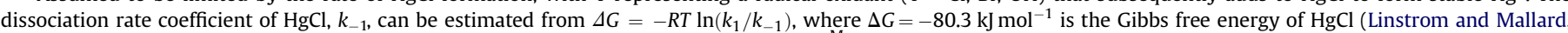

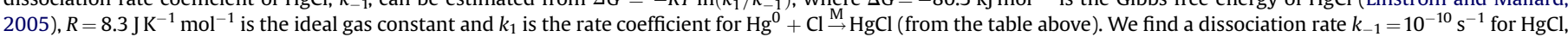
which is negligibly slow.

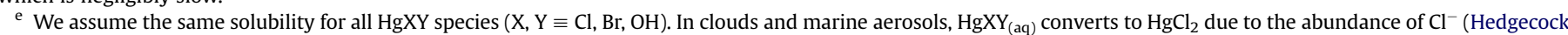
and Pirrone, 2001).

${ }^{\mathrm{f}}$ We use a rate coefficient of $9 \times 10^{-14} \mathrm{~cm}^{3} \mathrm{~mol}^{-1} \mathrm{~s}^{-1}$ (Pal and Ariya, 2004) in a sensitivity simulation (see Section 4).

equation implicitly assumes that all sea-salt aerosols deposit to the ocean and none enter the free troposphere. The bulk aerosol concentration $\left(c_{\mathrm{a}}\right)$ in Equation (9) is the volume-weighted mean over the $m$ size classes. We integrate the moderately-stiff system of Equations (1) and (11), using the MATLAB ode15s algorithm, for 6 days to reach diurnal steady state (i.e., identical diurnal cycles from one day to the next) and analyze the last day.

As a test of the above treatment of aerosol uptake and dry deposition, we simulated nighttime RGM under a range of wind speeds for the different data sets of Table 1 while holding other model parameters constant. Fig. 2 shows consistency with the observed decline of nighttime RGM with wind speed. While both dry deposition and sea-salt aerosol uptake increase with wind speed, aerosol uptake explains proportionally more loss with faster winds. In addition to wind speed, relative humidity also affects uptake, but the present data sets all have humidities near $80 \%$. Uptake is strongest at low relative humidity when the chloride concentration is greatest, despite the lesser aerosol liquid water content.

Fig. 3 shows the assumed relative diurnal profiles of $\mathrm{Br}, \mathrm{Cl}$ and $\mathrm{OH}$ while Table 1 gives the 24-h mean concentrations. $\mathrm{OH}$ concentrations are monthly mean values from the GEOS-Chem model (Park et al., 2004). For Cl we assume a 24-h mean concentration of $1.5 \times 10^{4}$ atoms $\mathrm{cm}^{-3}$, typical of values previously inferred for the MBL (Singh et al., 1996; Wingenter et al., 2005); this makes $\mathrm{Cl}$ only a minor oxidant of $\mathrm{Hg}^{0}$, as discussed below. For $\mathrm{Br}$ we adjust the 24-h concentration to best match the RGM diurnal amplitude, then calculate the associated $\mathrm{BrO}$ concentration from photochemical steady state (Platt and Janssen, 1995). We find daytime mean concentrations $0.6-1.2 \mathrm{ppt} \mathrm{BrO}$ are sufficient to explain the diurnal cycle in most conditions but we need to assume higher $\mathrm{Br}$ concentrations for the Atlantic, corresponding to $5.2 \mathrm{ppt}$ $\mathrm{BrO}$, and this is discussed below.

Observations of RGM concentrations at mountain sites and from aircraft show an increase from the boundary layer to the free troposphere (Swartzendruber et al., 2006; Sillman et al., 2007). An implication is that entrainment from above could be a significant source of RGM to the MBL. The GEOS-Chem global simulation (Selin et al., 2007) gives $\mathrm{Hg}^{\mathrm{II}}$ concentrations (RGM + particulate $\mathrm{Hg}^{\mathrm{II}}$ ) in the range $20-50 \mathrm{pg} \mathrm{m}^{-3}$ in the lower free troposphere over the regions examined here. If all of that $\mathrm{Hg}^{\text {II }}$ were RGM our model would overestimate mean MBL RGM concentrations as well as underestimate the relative amplitudes of diurnal cycles. We find a better match in our box model by entraining free-tropospheric RGM concentrations in the range $10-20 \mathrm{pg} \mathrm{m}^{-3}$ as given in Table 1 . These values are within the wide range of the few free-tropospheric observations (Swartzendruber et al., 2006; Sillman et al., 2007), and could be accommodated in the GEOS-Chem model if half of $\mathrm{Hg}^{\text {II }}$ were in particulate form.

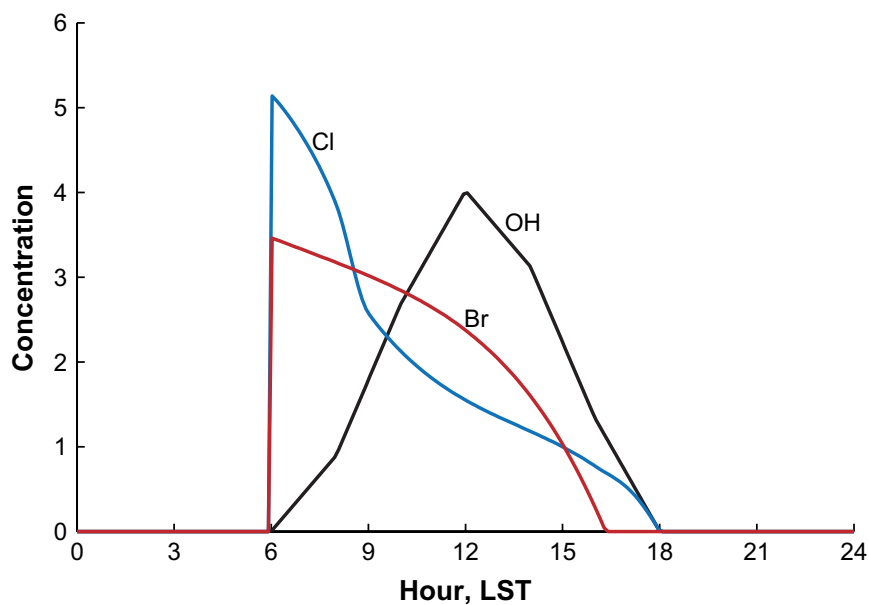

Fig. 3. Diurnal profiles of MBL oxidants normalized to a 24-h mean of 1. [OH] (black) from Brasseur et al. (1999); [Br] (red) and [Cl] (blue) from Pszenny et al. (2004). Table 1 gives the 24-h model mean concentrations of oxidants for each data set. (For interpretation of the references to colour in this figure legend, the reader is referred to the web version of this article.) 


\section{Model RGM diurnal cycles and budget}

Fig. 1 shows simulations of RGM for each observed region. The model reproduces major features of all RGM data sets: nighttime minimum, early morning rise, and midday peak before 13 LST. The peak-to-peak diurnal amplitudes in the model are 0.4-3.5 times the 24-h mean, as compared to 1-3 in the field data, indicating that the model RGM lifetime is consistent with observations. The consistency in 24-h mean concentrations reflects the choice of entrained RGM concentration (Section 3). At Okinawa, the simulated mean exceeds measurements by a factor of 2 . Since less entrainment would imply decreasing RGM with altitude and the relative diurnal cycle is underestimated by a factor of 2 , we believe that the RGM sinks are underestimated. Sea-salt aerosols generated in the surf zone may explain the discrepancy.

We find that the RGM observations are most consistent with $2-9 \times 10^{5}$ atoms $\mathrm{Br} \mathrm{cm}^{-3}$ (24-h mean) over the midlatitude and subtropical Pacific and at Okinawa (Table 1). Using photochemical steady-state equations and $\mathrm{O}_{3}$ measurements, the corresponding peak $\mathrm{BrO}$ concentrations are $0.6 \mathrm{ppt}$ in the Pacific midlatitudes, $0.8 \mathrm{ppt}$ in the Pacific subtropics, and $1.2 \mathrm{ppt}$ at Okinawa. These are within the large range of $\mathrm{BrO}$ observations in the MBL and consistent with higher BrO in coastal zones (Leser et al., 2003).

Simulations of the Atlantic data reproduce the relative diurnal amplitude (3.5 in the model vs. 3 in observations) but the maximum is too early in the day. Matching the diurnal amplitude requires $4.3 \times 10^{6}$ atoms $\mathrm{Br} \mathrm{cm}^{-3}$ (24-h mean), corresponding to $5.2 \mathrm{ppt} \mathrm{BrO}$ at sunrise. While there are few observations exceeding 2 ppt BrO in the remote MBL (Leser et al., 2003), the strong winds of the Atlantic cruise should have generated abundant sea-salt aerosols that might support such high Br levels. The strong winds also shorten the RGM lifetime to under $1 \mathrm{~h}$ (Table 1), so that the RGM diurnal cycle follows that of its Br-driven source (Fig. 3). This implies in turn a $\mathrm{Hg}^{0}$ loss of $0.15 \mathrm{ng} \mathrm{m}^{-3} \mathrm{~d}^{-1}$ which should induce a diurnal cycle in $\mathrm{Hg}^{0}$ concentrations but the observations show no such cycle. The high-wind conditions of the Atlantic cruise may challenge the steady-state assumption used in the model.

Sea-salt aerosols contain $80-90 \%$ of the total $\mathrm{MBL} \mathrm{Hg}^{\mathrm{II}}$ in the model. That is $25-45 \mathrm{pg} \mathrm{Hg}^{\mathrm{II}} \mathrm{m}^{-3}$ under most conditions. The simulation of the Atlantic data has up to $100 \mathrm{pg} \mathrm{Hg}^{\mathrm{II}} \mathrm{m}^{-3}$ or $95 \%$ of $\mathrm{Hg}^{\mathrm{II}}$ in aerosols. These values compare well with measurements of $5-40 \mathrm{pg} \mathrm{Hg}^{\mathrm{II}} \mathrm{m}^{-3}$ (mean $20 \mathrm{pg} \mathrm{m}^{-3}$ ) in coarse marine aerosol in Florida (Malcolm et al., 2003). Measurements in Alabama found somewhat lower values, $13 \mathrm{pg} \mathrm{Hg}^{\mathrm{II}} \mathrm{m}^{-3}$, in total aerosol samples from airmasses originating over the Gulf of Mexico (Engle et al., 2008). Jaffe et al. (2005) reported only $3 \mathrm{pg} \mathrm{m}^{-3}$ of particulate $\mathrm{Hg}$ from the Okinawa site but their instrument excluded coarse aerosols and hence most sea-salt aerosol mass.

Fig. 4 gives steady-state 24-h average budgets of RGM sources and sinks in the model MBL for the Pacific and Okinawa cases. We do not present the Atlantic case because the model does not fit these observations well. From Fig. 4 we see that $\mathrm{Hg}^{0}+\mathrm{Br}$ is the largest source of RGM, supplying 35-60\%. Subsidence from the free troposphere is the next largest budget term, accounting for $25-40 \%$ of RGM in the MBL. $\mathrm{Hg}^{0}+\mathrm{O}_{3}$ provides most of the remaining chemical source $(5-20 \%) \cdot \mathrm{Hg}^{0}+\mathrm{Cl}$ plays a minor role (3-7\%), but it could be larger if $\mathrm{Hg}^{0}+\mathrm{Cl}$ kinetics are faster than assumed or if $\mathrm{Cl}$ concentrations are greater; this would imply a somewhat smaller contribution from $\mathrm{Hg}^{0}+\mathrm{Br}$.

One the sink side, $80-90 \%$ of MBL RGM enters the ocean. Uptake into sea-salt aerosols and their subsequent deposition contributes $65-80 \%$ of the total RGM loss for the Pacific cruise and Okinawa, while direct dry deposition of RGM contributes $10-15 \%$. For the higher wind speeds that were observed in the Atlantic subtropics, the fraction of RGM lost through sea-salt aerosols rises to $90 \%$. The

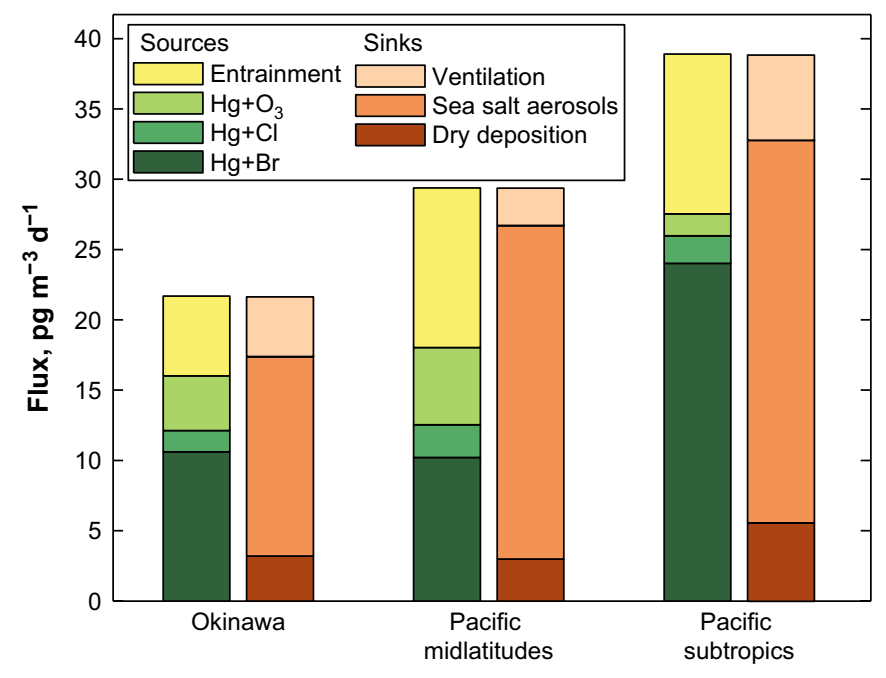

Fig. 4. Model budgets of RGM sources and sinks in the marine boundary layer. Values are 24-h averages at steady state.

RGM lifetimes range from $50 \mathrm{~min}$ (Atlantic subtropics) to $8 \mathrm{~h}$ (Okinawa).

Ventilation to the free troposphere provides a sink for $10-20 \%$ of RGM in the MBL, partly compensating for entrainment. An entrainment velocity of $0.5 \mathrm{~cm} \mathrm{~s}^{-1}$ at the top of a $750 \mathrm{~m}$ thick boundary layer gives a $40 \mathrm{~h}$ residence time for air in the MBL. Combined with the $\sim 100 \mathrm{~d}$ chemical lifetime of $\mathrm{Hg}^{0}$ under most conditions, this implies that no more than $3 \%$ of $\mathrm{Hg}^{0}$ emitted into the MBL is oxidized before escaping to the free troposphere above. A corollary is that most of the $\mathrm{Hg}^{\text {II }}$ formed within the MBL has passed through the free troposphere as $\mathrm{Hg}^{0}$. Mercury deposition to the ocean is thus mainly derived from the global mercury pool, rather than from marine emissions in a closed MBL cycle.

The total chemical production of RGM in the model is $15-28 \mathrm{pg} \mathrm{m}^{-3} \mathrm{~d}^{-1}$, excluding the Atlantic. This is less than $2 \%$ loss of $\mathrm{Hg}^{0}$ per day and below the $4-8 \mathrm{pg} \mathrm{m}^{-3} \mathrm{~h}^{-1}$ limit which would produce an observable diurnal cycle. Thus our model is consistent with the observed absence of diurnal $\mathrm{Hg}^{0}$ variation without invoking a daytime $\mathrm{Hg}^{0}$ source to compensate for the photochemical $\mathrm{Hg}^{0}$ sink.

As mentioned in the Introduction, there are large uncertainties regarding gas-phase $\mathrm{Hg}$ chemistry, with most previous studies assuming $\mathrm{OH}$ and $\mathrm{O}_{3}$ to be the major $\mathrm{Hg}^{0}$ oxidants. Fig. 1 shows the diurnal cycle of RGM that would result from a fast $\mathrm{Hg}^{0}+\mathrm{OH}$ reaction (Pal and Ariya, 2004) plus $\mathrm{Hg}^{0}+\mathrm{O}_{3}$ and without $\mathrm{Hg}+$ halogen reactions. In this model RGM rises significantly only after 9 LST, due to the slow morning rise of $\mathrm{OH}$ (Nowak et al., 2001). In contrast, RGM simulated with halogen oxidants increases at sunrise, as it does in the observations. The RGM peak due to $\mathrm{Hg}^{0}+\mathrm{OH}(14-15$ LST) is delayed several hours relative to the observations and base simulation. Only when the apparent RGM lifetime is $\sim 1 \mathrm{~h}$ or less, as in the subtropical Atlantic data, is the $\mathrm{Hg}^{\mathrm{O}}+\mathrm{OH}$ reaction consistent with the observed time of peak RGM. But reproducing the observed diurnal amplitude in the Atlantic data with the $\mathrm{Hg}^{0}+\mathrm{OH}$ reaction still requires large additional photochemical RGM sources. Due to the deficiencies in the Atlantic simulation with oxidation by either $\mathrm{OH}$ or $\mathrm{Br}$ (described above), the Atlantic data alone do not resolve the major oxidant. Nevertheless, the majority of available RGM data are more consistent with $\mathrm{Hg}^{0}$ oxidation by $\mathrm{Br}$, due to the earlier onset of bromine photochemistry. These tests cannot entirely reject the $\mathrm{Hg}^{0}+\mathrm{OH}$ reaction from a model that also includes $\mathrm{Hg}+$ halogen reactions, but any significant contribution from $\mathrm{OH}$ would cause simulated RGM concentrations to lag behind the data. 
While we have included the gas-phase $\mathrm{Hg}^{0}+\mathrm{O}_{3}$ reaction (Hall, 1995) in our simulations, several investigators have challenged its mechanism or atmospheric relevance (Shepler and Peterson, 2003; Calvert and Lindberg, 2005; Hynes et al., 2008). This reaction is a small source of MBL RGM in our model (5-20\%), and it has little diurnal variability, so its contribution could be replaced with a larger entrainment flux from the free troposphere. Such an increase would in fact better fit the observed and model values of RGM concentrations in the free troposphere.

\section{Conclusions}

We have analyzed atmospheric observations of reactive gaseous mercury (RGM) from Pacific and Atlantic cruises and from Okinawa in terms of mercury chemistry and deposition in the marine atmosphere. The dominant feature of the observations is a consistent diurnal cycle of concentrations with midday maximum, nighttime minimum, sharp increase after sunrise, and sharp decrease in afternoon. The early morning rise and midday peak implicate an RGM source from $\mathrm{Hg}^{0}$ oxidation by halogen atoms. The relative diurnal amplitude implies an RGM lifetime of only a few hours. Nighttime RGM is anticorrelated with wind speed, pointing to a fast deposition sink. In contrast to RGM, $\mathrm{Hg}^{0}$ shows no significant diurnal cycle in the observations.

We developed a box model for the marine boundary layer (MBL) to examine the consistency between the RGM data and current understanding of RGM sources and sinks, assuming that all gasphase $\mathrm{Hg}^{\mathrm{II}}$ species are measured as RGM. After choosing concentrations of $\mathrm{Br}$ and free-tropospheric RGM within observational constraints to best match the amplitude and mean of the RGM diurnal cycle, we find that the observed cycle is consistent with a major RGM source from oxidation of $\mathrm{Hg}^{0}$ by $\mathrm{Br}$ atoms. The implied MBL BrO concentrations are in the range 0.6-1.2 ppt, consistent with available data, although simulation of the Atlantic cruise data requires 5 ppt $\mathrm{BrO}$. Oxidation of $\mathrm{Hg}^{0}$ by $\mathrm{Cl}$ atoms and ozone is much smaller. A sensitivity simulation with $\mathrm{Hg}^{0}$ oxidation mainly by $\mathrm{OH}$ generates a later rise and peak of RGM than observations, suggesting that the reaction is unimportant. The dominance of $\mathrm{Br}$ as a $\mathrm{Hg}^{0}$ oxidant in the MBL was previously reported in box model calculations by Hedgecock et al. (2004, 2005), using older kinetic data for the $\mathrm{Hg}^{0}+\mathrm{Br}$ reaction (Ariya et al., 2002) that implied much faster oxidation than the more recent data used here (Goodsite et al., 2004). This resulted in daytime $\mathrm{Hg}^{0}$ depletion inconsistent with observations unless a compensating diurnal cycle in oceanic emission was assumed. The slower rates used here yield a $\mathrm{Hg}^{0}$ lifetime $\sim 100 \mathrm{~d}$ in the MBL, consistent with the observed lack of $\mathrm{Hg}^{0}$ diurnal variation.

Loss of RGM by dry deposition is too slow to account for the rapid decrease of RGM observed in the afternoon and evening hours. We find instead that the major loss pathway for RGM is uptake into sea-salt aerosols followed by aerosol deposition. We calculate the uptake rate with a physical mechanism accounting for sea-spray emission, aerosol deposition, aerosol hygroscopic growth and associated changes in $\mathrm{Cl}^{-}$concentration, and mass-transfer limitation. High $\mathrm{Cl}^{-}$concentrations present in sea-salt aerosols favor $\mathrm{HgCl}_{3}^{-}$and $\mathrm{HgCl}_{4}^{2-}$ complexes and enhance $\mathrm{Hg}^{\mathrm{II}}$ solubility. Our model thus predicts that $>80 \%$ of $\mathrm{MBL} \mathrm{Hg}^{\text {II }}$ is present as sea-salt aerosol rather than RGM. The associated sea-salt aerosol concentrations of $\mathrm{Hg}^{\mathrm{II}}$ are $25-45 \mathrm{pg} \mathrm{m}^{-3}$, consistent with the few observations available. Uptake by sea-salt aerosols accounts for $65-80 \%$ of RGM loss from the MBL in our simulation, and enables us to generally reproduce the observed phase and diurnal amplitude of the RGM observations. Considering direct dry deposition as well, $80-90 \%$ of RGM in the MBL deposits to the ocean.
We calculate a $\sim 100 \mathrm{~d}$ lifetime for $\mathrm{Hg}^{0}$ in the MBL against oxidation to $\mathrm{Hg}^{\mathrm{II}}$ in most conditions. Since ventilation of the MBL to the free troposphere takes place on a time scale $\sim 1 \mathrm{~d}$, the long $\mathrm{Hg}^{0}$ lifetime implies that $\mathrm{Hg}^{0}$ emitted from the ocean is ventilated to the free troposphere rather than oxidized in the MBL and returned to the ocean in a closed system. A corollary is that RGM formed and deposited within the MBL derives primarily from $\mathrm{Hg}^{0}$ transported in the free troposphere over long distances in the global mercury cycle.

Entrainment of RGM from the free troposphere in our model accounts for $25-40 \%$ of RGM in the MBL, second in importance to $\mathrm{Hg}^{0}$ oxidation by $\mathrm{Br}$ atoms. Selin et al. (2008) previously proposed that subtropical subsidence of high- $\mathrm{Hg}^{\mathrm{II}}$ air would be a major contributor to oceanic deposition of mercury. It provides a steady source of RGM to the MBL that our model requires to account for the observed magnitude of MBL concentrations and their relative diurnal amplitude. It is also consistent with the few RGM observations in the lower free troposphere.

Several key parameters and processes in our understanding of MBL mercury cycling have large uncertainties that require further study. Perhaps most important are measurements of $\mathrm{BrO}$ in the MBL with sub-ppt sensitivity, to test the hypothesis that $\mathrm{Br}$ is the dominant $\mathrm{Hg}^{0}$ oxidant. Mercury observations under intermediate winds $\left(6-10 \mathrm{~m} \mathrm{~s}^{-1}\right)$ are also necessary in light of our poor understanding of the RGM diurnal profile shape under strong winds. Vertical profiles of $\mathrm{Hg}^{\mathrm{II}}$ from the sea surface to the free troposphere, especially in the subtropical subsidence zones, would better constrain entrainment. Finally, $\mathrm{Hg}$ (aq) concentrations in sea-salt aerosols should be measured to test the hypothesis that sea-salt aerosol deposition is the dominant pathway for mercury deposition to the ocean.

\section{Acknowledgments}

This work was supported by the Atmospheric Chemistry Program of the U.S. National Science Foundation and by a U.S. Environmental Protection Agency (EPA) Science to Achieve Results (STAR) Graduate Fellowship to CDH. Statements in this publication reflect the authors' professional views and opinions and should not be construed to represent any determination or policy of the U.S. EPA. CDH thanks Elsie Sunderland, Lin Zhang, Monika Kopacz and Eric Leibensperger for helpful conversations.

\section{References}

Ariya, P.A., Khalizov, A., Gidas, A., 2002. Reaction of gaseous mercury with atomic and molecular halogens: kinetics, product studies, and atmospheric implications. J. Phys. Chem. A 106, 7310-7320.

Ariya, P.A., Skov, H., Grage, M.M.L., Goodsite, M.E., 2008. Gaseous elemental mercury in the ambient atmosphere: review of the application of theoretical calculations and experimental studies for determination of reaction coefficients and mechanisms with halogens and other reactants. Adv. Quantum Chem. 55, 43-55.

Balabanov, N.B., Shepler, B.C., Peterson, K.A., 2005. Accurate global potential energy surface and reaction dynamics for the ground state of $\mathrm{HgBr}_{2}$. J. Phys. Chem. A 109 (39), 8765-8773.

Brasseur, G.P., Orlando, J.J., Tyndall, G.S., 1999. Atmospheric Chemistry and Global Change. Oxford University Press, Oxford.

Brooks, S.B., Saiz-Lopez, A., Skov, H., Lindberg, S.E., Plane, J.M.C., Goodsite, M.E. 2006. The mass balance of mercury in the springtime arctic environment. Geophys. Res. Lett. 33 (13), L13812.

Calvert, J.G., Lindberg, S.E., 2005. Mechanisms of mercury removal by $\mathrm{O}_{3}$ and $\mathrm{OH}$ in the atmosphere. Atmos. Environ. 39, 3355-3367.

Clever, H.L., Johnson, S.A., Derrick, M.E., 1985. The solubility of mercury and some sparingly soluble mercury salts in water and aqueous-electrolyte solutions. J. Phys. Chem. Ref. Data 14 (3), 631-681.

Cohen, M., Artz, R., Draxler, R., Miller, P., Poissant, L., Niemi, D., et al., 2004. Modeling the atmospheric transport and deposition of mercury to the Great Lakes. Environ. Res. 95 (3), 247-265. doi:10.1016/j.envres.2003.11.007.

Donohoue, D.L., Bauer, D., Cossairt, B., Hynes, A.J., 2006. Temperature and pressure dependent rate coefficients for the reaction of $\mathrm{Hg}$ with $\mathrm{Br}$ and the reaction of $\mathrm{Br}$ with $\mathrm{Br}$ : a pulsed laser photolysis-pulsed laser induced fluorescence study. J. Phys. Chem. A 110, 6623-6632. 
Donohoue, D.L., Bauer, D., Hynes, A.J., 2005. Temperature and pressure dependent rate coefficients for the reaction of $\mathrm{Hg}$ with $\mathrm{Cl}$ and the reaction of $\mathrm{Cl}$ with $\mathrm{Cl}$ : a pulsed laser photolysis-pulsed laser induced fluorescence study. J. Phys. Chem. A 109 (34), 7732-7741.

Engle, M.A., Tate, M.T., Krabbenhoft, D.P., Kolker, A., Olson, M.L., Edgerton, E.S., et al., 2008. Characterization and cycling of atmospheric mercury along the central US Gulf Coast. Appl. Geochem. 23 (3), 419-437. doi:10.1016/j.apgeochem.2007.12.024.

Faloona, I., Lenschow, D.H., Campos, T., Stevens, B., van Zanten, M., Blomquist, B., et al., 2005. Observations of entrainment in eastern Pacific marine stratocumulus using three conserved scalars. J. Atmos. Sci. 62 (9), 3268-3285.

Goodsite, M.E., Plane, J.M.C., Skov, H., 2004. A theoretical study of the oxidation of $\mathrm{Hg}^{0}$ to $\mathrm{HgBr}_{2}$ in the troposphere. Environ. Sci. Technol. 38 (6), 1772-1776.

Hall, B., 1995. The gas phase oxidation of elemental mercury by ozone. Water Air Soil Pollut. 80, 301-315.

Hedgecock, I.M., Pirrone, N., 2001. Mercury and photochemistry in the marine boundary layer-modelling studies suggest the in situ production of reactive gas phase mercury. Atmos. Environ. 35 (17), 3055-3062.

Hedgecock, I.M., Pirrone, N., 2004. Chasing quicksilver: modeling the atmospheric lifetime of $\mathrm{Hg}-(\mathrm{g})(0)$ in the marine boundary layer at various latitudes. Environ. Sci. Technol. 38 (1), 69-76.

Hedgecock, I.M., Pirrone, N., Sprovieri, F., Pesenti, E., 2003. Reactive gaseous mercury in the marine boundary layer: modelling and experimental evidence of its formation in the Mediterranean region. Atmos. Environ. 37, S41-S49.

Hedgecock, I.M., Pirrone, N., Trunfio, G.A., Sprovieri, F., 2006. Integrated mercury cycling, transport, and air-water exchange (MECAWEx) model. J. Geophys. Res. 111 (D20). doi:10.1029/2006JD007117.

Hedgecock, I.M., Trunfio, G.A., Pirrone, N., Sprovieri, F., 2005. Mercury chemistry in the MBL: Mediterranean case and sensitivity studies using the AMCOTS (atmospheric mercury chemistry over the sea) model. Atmos. Environ. 39 (38), 7217-7230.

Hignett, P., 1991. Observations of diurnal variation in a cloud-capped marine boundary layer. J. Atmos. Sci. 48 (12), 1474-1482.

Holmes, C.D., Jacob, D.J., Yang, X., 2006. Global lifetime of elemental mercury against oxidation by atomic bromine in the free troposphere. Geophys. Res. Lett. 33 (20). doi:10.1029/2006GL027176.

Hynes, A.J., Donohoue, D.L., Goodsite, M.E., Hedgecock, I.M., 2008. Our current understanding of major chemical and physical processes affecting mercury dynamics in the atmosphere and at air-water/terrestrial interfaces. In Pirrone, N., Mason, R.P. (Eds.), Mercury Fate and Transport in the Global Atmosphere. UNEP Global Mercury Partnership.

Jaffe, D., Prestbo, E., Swartzendruber, P., Weiss-Penzias, P., Kato, S., Takamir, A., et al., 2005. Export of atmospheric mercury from Asia. Atmos. Environ. 39, 3029-3038.

Keene, W.C., Stutz, J., Pszenny, A.A.P., Maben, J.R., Fischer, E.V., Smith, A.M., et al., 2007. Inorganic chlorine and bromine in coastal New England air during summer. J. Geophys. Res. Atmos. 112 (D10). doi:10.1029/2006JD007689.

Landis, M.S., Stevens, R.K., Schaedlich, F., Prestbo, E.M., 2002. Development and characterization of an annular denuder methodology for the measurement of divalent inorganic reactive gaseous mercury in ambient air. Environ. Sci. Technol. 36 (13), 3000-3009.

Laurier, F., Mason, R.P., 2007. Mercury concentration and speciation in the coastal and open ocean boundary layer. J. Geophys. Res. 112 (D6), D06302. doi:10.1029/ 2006JD007320.

Laurier, F.J.G., Mason, R.P., Whalin, L., Kato, S., 2003. Reactive gaseous mercury formation in the North Pacific Ocean's marine boundary layer: a potential role of halogen chemistry. J. Geophys. Res. 108 (D17), 4529. doi:10.1029/2003JD003625.

Leser, H., Honninger, G., Platt, U., 2003. MAX-DOAS measurements of BrO and NO in the marine boundary layer. Geophys. Res. Lett. 30 (10), 1537. doi:10.1029/ 2002GL015811.

Lewis, E.R., Schwartz, S.E., 2004. Sea Salt Aerosol Production. American Geophysical Union, Washington, DC

Lewis, E.R., Schwartz, S.E., 2006. Comment on "size distribution of sea-salt emissions as a function of relative humidity". Atmos. Environ. 40 (3), 588-590.

Lin, C.J., Pongprueksa, P., Lindberg, S.E., Pehkonen, S.O., Byun, D., Jang, C., 2006. Scientific uncertainties in atmospheric mercury models I: model science evaluation. Atmos. Environ. 40 (16), 2911-2928.

Lindberg, S., Bullock, R., Ebinghaus, R., Engstrom, D., Feng, X.B., Fitzgerald, W., et al. 2007. A synthesis of progress and uncertainties in attributing the sources of mercury in deposition. Ambio 36 (1), 19-32.

Lindqvist, O., Rodhe, H., 1985. Atmospheric mercury - a review. Tellus B 37 (3), 136-159.

Linstrom, P.J., Mallard, W.G., 2005. NIST Chemistry WebBook. NIST Standard Reference Database Number 69. National Institute of Standards and Technology, Gaithersburg, MD.

Malcolm, E.G., Keeler, G.J., Landis, M.S., 2003. The effects of the coastal environment on the atmospheric mercury cycle. J. Geophys. Res. 108 (D12). doi:10.1029/ 2002JD003084.
Mason, R.P., Sheu, G.R., 2002. Role of the ocean in the global mercury cycle. Global Biogeochem. Cycles 16 (4), 1093.

Mergler, D., Anderson, H.A., Chan, L.H.M., Mahaffey, K.R., Murray, M., Sakamoto, M. et al., 2007. Methylmercury exposure and health effects in humans: a worldwide concern. Ambio 36 (1), 3-11.

Nowak, J.B., Davis, D.D., Chen, G., Eisele, F.L., Mauldin, R.L., Tanner, D.J., et al., 2001. Airborne observations of DMSO, DMS, and $\mathrm{OH}$ at marine tropical latitudes. Geophys. Res. Lett. 28 (11), 2201-2204.

Pal, B., Ariya, P.A., 2004. Gas-phase HO-initiated reactions of elemental mercury: kinetics and product studies, and atmospheric implications. Environ. Sci. Technol. 38 (21), 5555-5566.

Park, R.J., Jacob, D.J., Field, B.D., Yantosca, R.M., Chin, M., 2004. Natural and transboundary pollution influences on sulfate-nitrate-ammonium aerosols in the United States: implications for policy. J. Geophys. Res. 109, D15204. doi:10.1029/ 2003JD004473.

Petersen, G., Bloxam, R., Wong, S., Munthe, J., Kruger, O., Schmolke, S.R., et al., 2001 A comprehensive Eulerian modelling framework for airborne mercury species: model development and applications in Europe. Atmos. Environ. 35 (17), 30633074.

Platt, U., Janssen, C., 1995. Observation and role of the free radicals $\mathrm{NO}_{3}, \mathrm{ClO}, \mathrm{BrO}$ and IO in the troposphere. Faraday Discuss. 100, 175-198.

Pszenny, A.A.P., Moldanov, J., Keene, W.C., Sander, R., Maben, J.R., Martinez, M., et al., 2004. Halogen cycling and aerosol pH in the Hawaiian marine boundary layer. Atmos. Chem. Phys. 4, 147-168.

Sander, R., 1999. Modeling atmospheric chemistry: interactions between gas-phase species and liquid cloud/aerosol particles. Surv. Geophys. 20 (1), 1-31.

Seigneur, C., Vijayaraghavan, K., Lohman, K., 2006. Atmospheric mercury chemistry: sensitivity of global model simulations to chemical reactions. J. Geophys. Res. 111 (D22). doi:10.1029/2005JD006780.

Seinfeld, J.H., Pandis, S.N., 2006. Atmospheric Chemistry and Physics: From Air Pollution to Climate Change. John Wiley \& Sons, New York.

Selin, N.E., Jacob, D.J., Park, R.J., Yantosca, R.M., Strode, S., Jaegle, L., et al., 2007. Chemical cycling and deposition of atmospheric mercury: global constraints from observations. J. Geophys. Res. 112 (D2). doi:10.1029/2006JD007450.

Selin, N.E., Jacob, D.J., Yantosca, R.M., Strode, S., Jaegle, L., Sunderland, E.M., 2008. Global 3-D land-ocean-atmosphere model for mercury: present-day vs. preindustrial cycles and anthropogenic enrichment factors for deposition. Global Biogeochem. Cycles 22 (GB2011). doi:10.1029/2007GB003040.

Shepler, B.C., Peterson, K.A., 2003. Mercury monoxide: a systematic investigation of its ground electronic state. J. Phys. Chem. A 107 (11), 1783-1787.

Shia, R.L., Seigneur, C., Pai, P., Ko, M., Sze, N.D., 1999. Global simulation of atmospheric mercury concentrations and deposition fluxes. J. Geophys. Res. 104 (D19), 23747-23760

Sillman, S., Marsik, F.J., Al-Wali, K.I., Keeler, G.J., Landis, M.S., 2007. Reactive mercury in the troposphere: model formation and results for Florida, the northeastern United States, and the Atlantic Ocean. J. Geophys. Res. 112 (D23), D23305.

Singh, H.B., Thakur, A.N., Chen, Y.E., Kanakidou, M., 1996. Tetrachloroethylene as an indicator of low $\mathrm{Cl}$ atom concentrations in the troposphere (vol 23, pg 1529, 1996). Geophys. Res. Lett. 23 (19), 2713.

Strode, S.A., Jaegle, L., Jaffe, D.A., Swartzendruber, P.C., Selin, N.E., Holmes, C.D., et al., 2008. Trans-Pacific transport of mercury. J. Geophys. Res. 113, D15305. doi:10.1029/2007JD009428.

Strode, S.A., Jaegle, L., Selin, N.E., Jacob, D.J., Park, R.J., Yantosca, R.M., et al., 2007. Air-sea exchange in the global mercury cycle. Global Biogeochem. Cycles 21 (1). doi:10.1029/2006GB002766.

Stull, R.B., 1988. An Introduction to Boundary Layer Meteorology. Kluwer Academic, Dordrecht.

Swartzendruber, P.C., Jaffe, D.A., Prestbo, E.M., Weiss-Penzias, P., Selin, N.E., Park, R., et al., 2006. Observations of reactive gaseous mercury in the free troposphere at the Mount Bachelor Observatory. J. Geophys. Res. 111 (D24). doi:10.1029/2006JD007415.

Tackett, P.J., Cavender, A.E., Keil, A.D., Shepson, P.B., Bottenheim, J.W., Morin, S., et al., 2007. A study of the vertical scale of halogen chemistry in the Arctic troposphere during Polar Sunrise at Barrow, Alaska. J. Geophys. Res. Atmos. 112 (D7), D07306. doi:10.1029/2006JD007785.

von Glasow, R., Sander, R., Bott, A., Crutzen, P.J., 2002. Modeling halogen chemistry in the marine boundary layer - 1. Cloud-free MBL. J. Geophys. Res. 107 (D17), 4341. doi:10.1029/2001JD000942.

Wingenter, O.W., Sive, B.C., Blake, N.J., Blake, D.R., Rowland, F.S., 2005. Atomic chlorine concentrations derived from ethane and hydroxyl measurements over the equatorial Pacific Ocean: implication for dimethyl sulfide and bromine monoxide. J. Geophys. Res. Atmos. 110 (D20). doi:10.1029/2005JD005875.

Zhang, L., Gong, S., Padro, J., Barrie, L., 2001. A size-segregated particle dry deposition scheme for an atmospheric aerosol model. Atmos. Environ. 35, 549-560. 